\title{
Hubungan Semangat Belajar Sejarah dengan Hasil Belajar Siswa Kelas X SMA Negeri 5 Lubuklinggau
}

\author{
Agus Susilo ${ }^{1),}$, Sisca Arie Hanika ${ }^{2)}$ \\ ${ }^{1)}$ Program Studi Pendidikan Sejarah STKIP PGRI Lubuklinggau \\ ${ }^{2)}$ SMA Negeri 5 Lubuklinggau \\ a)agussusilo4590@gmail.com@gmail.com
}

Informasi Artikel

Tanggal Publikasi

31 Desember 2021

\section{Kata Kunci}

Semangat Belajar Sejarah

Hasil Belajar Siswa

\begin{abstract}
Abstrak
Tujuan penelitian ini adalah untuk mengetahui hubungan semangat belajar Sejarah dengan hasil belajar siswa Kelas X SMA Negeri 5 Lubuklinggau. Metode yang digunakan dalam penelitian ini adalah metode kuantitatif. Untuk menghitung penelitian ini, peneliti menggunakan tes yang diberikan kepada siswa. Dari hasil tes tersebut dapat diketahui tingkat keberhasilan dan hubungan antara semangat belajar dengan hasil belajar Sejarah di SMA Negeri 5 Lubuklinggau. Hasil dan pembahasan diketahui bahwa hasil statistik diketahui bahwa $\mathrm{H} 1$ dalam meningkatkan semangat belajar Sejarah dengan hasil belajar siswa di Kelas X IPS SMA Negeri 5 Lubuklinggau diterima dimana hasil nilai thitung 9,376 > 1,986. H1 diteima sedangkan Ho ditolak artinya terhadap hubungan yang dignifikan antara semangat belajar dengan hasil belajar sejarah. Hal ini menunjukan bahwa guru mata pelajaran sejarah mampu meningkatkan semangat belajar siswa melalui pemberian motivasi dan pemanfaatan media pembelajaran yang efektif dengan menggunakan kemajuan ilmu pengetahuan dan teknologi. Pengembangan diri yang didapatkan oleh guru di era digital ini harus diberikan kepada siswa melalui pembelajaran yang inovatif dan menumbuhkan semangat belajar siswa yang tinggi.
\end{abstract}

This is an open access article under the CC - BY license.

\section{PENDAHULUAN}

Keberhasilan dalam proses pembelajaran sangat dipengaruhi oleh kinerja guru dalam mengajar di kelas. Perubahan dalam mengajar ini adalah bagian dari kemajuan zaman yang semakin canggih, dimana dituntut untuk menyesuaikan diri dalam proses pengajaran. Komponen dalam pembelajaran yang menjadi penunjang dalam pembelajaran di kelas meliputi guru, siswa, tujuan, metode, media pembelajaran, dan evaluasi. Semua unsur tersebut saling bekerjasama untuk mewujudkan suasana pendidikan yang terbaik dimasa kini dan masa yang akan datang. Belajar pada dasarnya adalah proses interaksi yang dilakukan untuk memberi pengaruh kepada siswa, baik faktor tersebut secara internal maupun secara eksternal. Faktor internal sendiri meliputi minat, bakat, motivasi, semangat, dan tingkat kecerdasan. Sedangkan faktor eksternal sendiri berarti faktor yang berkaitan dengan prestasi belajar yang disesuaikan dengan tujuan yang ingin diharapkan (Joni, 2017).

Untuk meningkatkan semangat belajar didalam kelas tentunya membutuhkan perjuangan bagi penyelenggara pendidikan. Guru dalam Sekolah dinilai yang mampu untuk mengetahui tingkat psikologi anak didiknya. Guru sebagai penyelenggara pendidikan seyogyanya mampu dalam memahami perkembangan psikologi peserta didiknya (Sanjaya, 2016). Hal yang dapat membangkitkan semangat belajar siswa, tentunya adalah motivasi. Melalui motivasi dalam belajar yang diberikan guru kepada siswa akan berpengaruh pada tingkat keberhasilan belajar siswa selama mengikuti pembelajaran. Motivasi dalam diri siswa perlu ditumbuhkan supaya 
dalam belajar dapat memahami dan menguasai materi yang diajarkan oleh guru (Wa Fiana, 2018). Motivasi belajar siswa akan berhasil dalam meraih hasil belajar jika dalam proses pembelajaran guru sebagai pengajar mampu menunjukkan perilaku belajar yang seharusnya ditiru. Motivasi belajar juga dapat datang dari nasehatnasehat dalam pengajaran tersebut. Sehingga dengan semangat yang ditujukkan oleh guru tersebut, semangat untuk belajar semakin besar (Suyuti dan Ervina, 2020).

Di era digital seperti saat ini, peran guru dalam mendesian pembelajaran sangat penting sekali. Media dinilai sangat efektif dalam menyalurkan materi pelajaran yang sangat baik. Dilain pihak kemajuan zaman harus dapat mampu diimbangi oleh keberadaan media pembelajaran tersebut. Kemampuan guru dalam menggunakan media pembelajaran sangat mempengaruhi semangat belajar siswa dikelas (Widayanti, 2013). Pembelajaran Sejarah di SMA sendiri pada dasarnya sudah menggunakan kurikulum 2013 dan pengembangannya sejak tahun 2013 yang dimulai dari siswa kelas 10 dan kelas 11. Sistem pembelajaran yang ada saat ini harus disesuaikan dengan perkembangan zaman yang semakin canggih. Guru Sejarah tidak dapat hanya mengandalkan model pembelajaran ceramah saja seiring majunya zaman ini. Beberapa permasalahan yang menjadi problem dalam pembelajaran Sejarah harus dapat diselesaikan dengan tepat (Susilo \& Sarkowi, 2018).

Sistem pembelajaran di SMA Negeri 5 Lubuklinggau saat ini telah banyak menggunakan kurikulum 2013. Mata pelajaran Sejarah sendiri telah lama berbasis kurikulum 2013. Guru dalam mengajar di era globalisasi memang dituntut untuk lebih aktif dan kreatif. Guru Sejarah di SMA Negeri 5 Lubuklinggau telah banyak menggunakan strategi yang baik dengan dipadukan dengan media pembelajaran kreatif dan inovatif. Namun banyak hasil belajar Sejarah yang belum memuaskan untuk penilaian akhir siswa. Beberapa siswa mengalami banyak kendala dalam belajar, dikarenakan materi Sejarah yang masih sulit untuk dipahami. Siswa tidak hanya menginginkan sistem pembelajaran dengan media dan strategi yang bagus dari guru, namun juga terkait pengaruh dari guru sebagai pengajar. Dalam pengembangan sistem pembelajaran, Guru Sejarah dapat mengembangkan diri dengan berbagai kegiatan, seperti membuat media pembelajaran yang inovatif dan menyenangkan, menggunakan model dan strategi pembelajaran yang sesuai dengan keadaan Sekolah. Guru dalam mengajar tidak hanya berpatokan pada hasil belajar saja, namun bagaimana memberi pengaruh agar proses pembelajaran tersebut menjadi hidup. Pembelajaran yang menyenangkan tentunya berpengaruh bagi hasil belajar. Maka atas problem diatas maka penelitian ini akan membahas tentang hubungan semangat belajar Sejarah dengan hasil belajar siswa SMA Negeri 5 Lubuklinggau Kelas X.

\section{METODE PENELITIAN}

Dalam penelitian ini, metode penelitian yang digunakan dalam penelitian adalah metode penelitian kuantitatif. Menurut (Arikunto, 2012), metode penelitian adalah langkah atau strategi yang dilakukan oleh seorang peneliti untuk mengumpulkan data dalam penelitian yang sedang dikembangkannya. Langkah-langkah dalam penelitian ini adalah menentukan kelas/kelompok perlakuan, melakukan pre test yang dilakukan untuk mengetahui kemampuan awal siswa sebelum dilakukan treatment (perlakuan), melakukan treatment (perlakuan) dengan menumbuhkan semangat belajar Sejarah pada kelas X IPS, melakukan post test dilakukan agar dapat mengetahui pengetahuan siswa setelah dilakukan treatment (perlakuan). Metode kuantitatif sendiri memiliki arti sebagai metode yang membahas penelitian yang hasil dari kajiannnya berupa angka-angka. Pada penelitian ini, peneliti berusaha untuk menentukan sampel atau populasi dengan teknik yang digunakannya adalah secara random untuk mengumpulkan data. Instrumen data yang digunakan tersebut akhirnya diujikan secara benar untuk menentukan tujuan akhirnya dengan pengujian hipotesis (Sugiyono, 2015).

Penelitian ini dilakukan di SMA Negeri 5 Lubuklinggau yang mana kelas dipilih secara random adalah kelas X IPS. Penelitian ini dilakukan pada semester ganjil tahun ajaran 2021/2022. Alasan penelitian ini dilakukan di SMA Negeri 5 Lubuklinggau karena SMA tersebut belum menjadi kajian dalam penelitian. Selain itu, beberapa pertimbangan seperti semangat siswa yang besar untuk dilihat dalam penelitiannya dan dukungan guru Sejarah sebagai mitra peneliti menjadi pertimbangan bahwa penelitian ini layak dilakukan.

Dalam penelitian ini, peneliti mengunakan teknik penelitian yang bertujuan untuk mengetahui hubungan semangat belajar Sejarah dengan hasil belajar siswa SMA Negeri 5 Lubuklinggau Kelas X. Hasil belajar sendiri berarti penelitian ini agar hasilnya dapat diketahui harus mengunakan pengetahuan dan pemahaman yang teliti untuk mengetahui hasil dari proses pembelajaran tersebut yang meliputi pengembangan kemampuan 
rasional atau akal (kognitif) (Aman, 2011). Instumen yang digunakan dalam penelitian ini adalah berupa tes pilihan ganda. Melalui tes tersebut siswa akan menjawab semua pertanyaan yang diberikan oleh peneliti.

Teknik analisis data yang digunakan dalam penelitian ini adalah teknik analisis data yang menggunakan program SPSS versi 19 dengan Uji Beda Rata-Rata (Uji Hipotesis). Proses penghitungan data kuantitatif ini dimulai dengan menggunakan analisis perbedaan dengan data yang terlebih dahulu dilakukan uji normalitas dan uji homogenitas dari kelompok tersebut. Setelah proses tersebut selesai maka peneliti menggunakan uji kesamaan dua rata-rata. Langkah tersebut digunakan untuk mengetahui data yang peneliti sedang teliti.

\section{HASIL DAN PEMBAHASAN}

\section{Hubungan Semangat Belajar Sejarah dengan Hasil Belajar Siswa}

Semangat belajar adalah modal berharga dalam meningkatkan kemampuan untuk memahami dan menganalisis sebuah materi pembelajaran yang memberi pengaruh bagi hasil belajar siswa di Sekolah. Semangat belajar dalam pembelajaran Sejarah yang dikaji ini tujuannya untuk memberikan pengaruh yang besar dalam proses pembelajaran. Penelitian yang dilakukan oleh peneliti bertujuan untuk mengukur tingkat semangat belajar Sejarah dan hasil belajar. Hasil penelitian yang dilakukan oleh peneliti menunjukkan bahwa angket menunjukkan semangat belajar Sejarah di SMA Negeri 5 Lubuklinggau sudah sangat baik dengan perolehan data tersebut. Atas hasil tersebut, maka dapat disimpulkan bahwa semangat belajar Sejarah yang peneliti lakukan dapat memberikan pengaruh yang signifikan dengan hasil belajar.

Dapat diketahui bahwa hasil penelitian yang dikembangkan oleh peneliti tentang semangat belajar Sejarah terhadap siswa, data variabel $\mathrm{X}$ tentang semangat belajar siswa terlihat bahwa rata-rata tingkat semangat belajar Sejarahnya dalam katogori sangat baik dengan nilai skor yang dicapai dalam perhitungan variabel X hasilnya adalah 60,5 pada pretest dan 83 pada post test. Dilihat dari tabel klasifikasi semangat belajar Sejarah siswa yang dikemukakan oleh (Sugiyono, 2015) dimana skor akhir 83 adalah masuk katogori sangat baik. Untuk mengetahui pengaruh antara hasil belajar kelas eksperimen dan kelas kontrol dapat dilihat pada gambar ini.

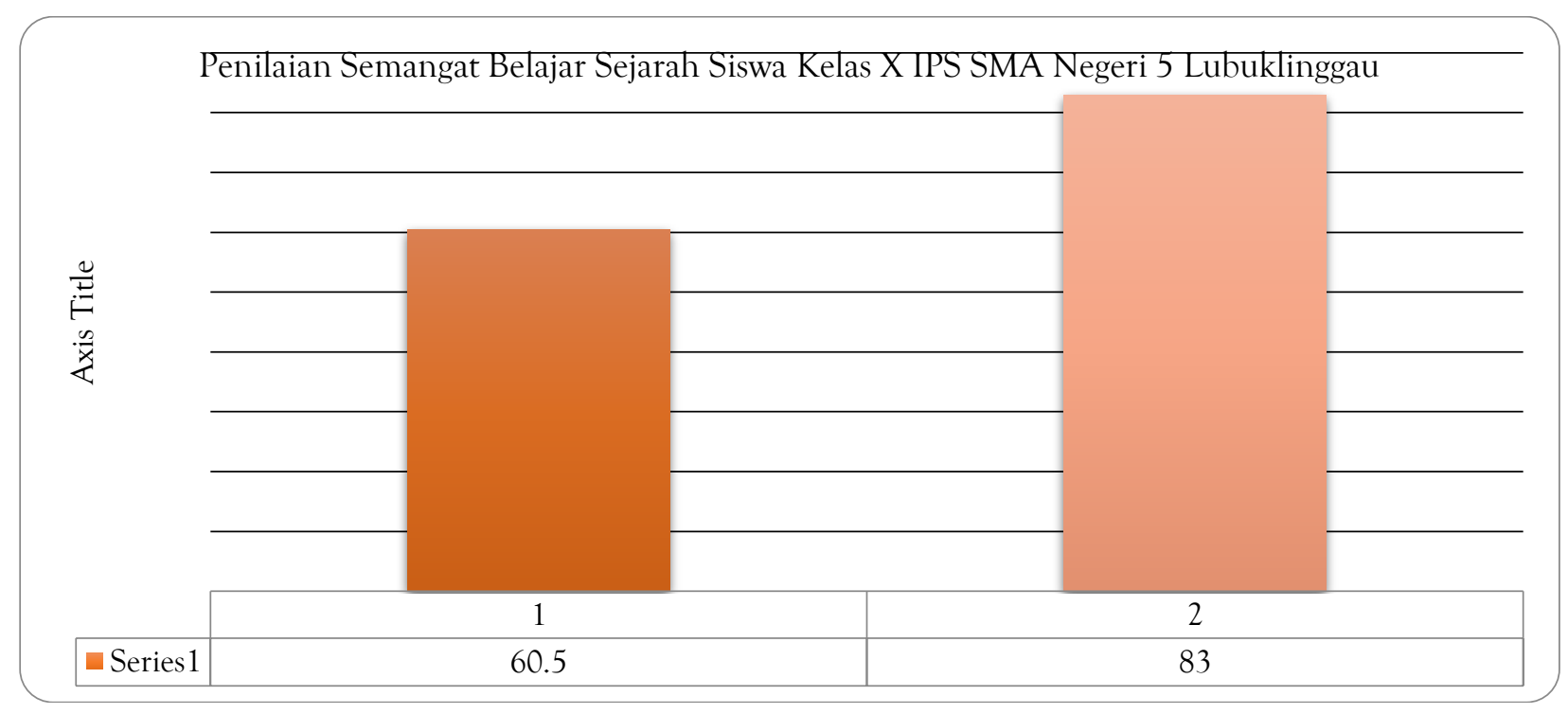

\begin{tabular}{lcc}
\hline Kelas X IPS SMA Negeri 5 Lubuklinggau & Pre-Test & Post-Test \\
\hline X IPS & 60,5 & 83 \\
\hline
\end{tabular}

Gambar 1. Diagram hasil penilaian semangat belajar Sejarah siswa Kelas X IPS SMA Negeri 5 Lubuklinggau

Selain diketahui sistem penghitungan dengan skor angket semangat belajar Sejarah dan hasil belajar. penelitian ini dilanjutkan dengan analisis inferensial yang mana peneliti menguji hipotesis. Hasil dari analisis inferensial ini diperoleh dengan berdasarkan hasil penghitungan koefesien kolerasi (r), yaitu sebesar 0,788. Apabila mengacu pada interpretasi koefesien korelasi menurut Sugiyono, maka hasil koefesiensi tersebut berada pada katogori 0,600-0,799 atau kuat. Maka hal ini menunjukkan bahwa tingkat pengaruh semangat belajar sejarah dengan hasil belajar di SMA Negeri 5 Lubuklinggau sebesar 0,788. 
Dalam penelitian ini, diketahui bahwa pengujian hipotesis yang dilakukan untuk mengetahui hasilnya adalah tidak ada hubungan yang signifikan antara semangat belajar Sejarah dengan hasil belajar siswa yang peneliti dapatkan dengan menggunakan statistik uji signifikan dengan teknik product moment person yang kemudian dilanjutkan dengan uji t. Penghitungan nilai antara variabel $\mathrm{x}$ dan variabel y yang kemudian dilanjutkan dengan mencari nilai $t_{\text {hitung }}$ maka hasilnya didapatkan bahwa $t_{\text {hitung }}$ atau 9,376 dengan nilai $t_{\text {tabel }} 1,986$.

Maka dari pernyataan diatas dapat diketahui bahwa $\mathrm{H}_{1}$, yaitu ada pengaruh yang signifikan antara semangat belajar Sejarah dengan hasil belajar siswa di Kelas X IPS SMA Negeri 5 Lubuklinggau diterima. Oleh karena itu, nilai yanag didapatkan adalah nilai thitung 9,376 > 1,986. Sedangkan Ho yang tidak ada hubungan antara semangat belajar Sejarah dan hasil belajar siswa di kelas X IPS SMA Negeri 5 Lubuklinggau ditolak. Selanjutnya dapat diketahui bahwa statistik yang didapatkan menunjukkan ada pengaruh yang signifikan antara semangat belajar Sejarah dengan hasil belajar siswa di kelas X IPS SMA Negeri 5 Lubuklinggau.

Penelitian yang telah dilaksanakan dapat diketahui memberikan efek yang bagus dalam meningkatkan semangat belajar Sejarah siswa. Dalam menumbuhkan semangat belajar dan hasil belajar Sejarah yang optimal, Guru Sejarah harus mampu mengkolaborasikan antara media pembelajaran dengan model, strategi dan tujuan pembelajaran yang akan dikembangkannya. Pelajaran Sejarah yang diajarkan oleh guru kepada siswa harus memiliki manfaat yang baik. Belajar Sejarah tidak hanya sebatas mengetahui, namun lebih pada analisis seperti yang terdapat pada kurikulum 2013. Guru Sejarah harus terus mengasah kemampuannya dalam meningkatkan pembelajaran di kelas. Pembelajaran Sejarah yang menarik dan inovatif dapat berdampak positif bagi kemajuan siswa. Semangat siswa dalam belajar Sejarah menjadi meningkat dan hasil belajarnya juga mengalami peningkatan yang signifikansi.

Dari hasil penelitian diatas, penelitian tersebut sejalan dengan beberapa penelitian yang dilakukan peneliti sebelumnya. Penelitian ini relevan dengan penelitian yang dilakukan oleh (Hidayat, 2018) dengan judul penggunaan media peta pengaruhnya terhadap motivasi belajar Sejarah pada SMA Islam PB. Soedirman Cijantung Jakarta Timur. Hasil penelitian diketahui bahwa adanya hubungan antara penggunaan media peta IPS Sejarah terhadap motivasi belajar siswa kelas X IPS di SMA Islam PB. Soedirman Cijantung. Hal ini dapat dilihat dari nilai koefisien korelasi $\left(\mathrm{r}_{\mathrm{xy}}\right)$ sebesar 0,542 dengan tingkat hubungan kuat.

Penelitian selanjutnya dilakukan oleh (Joni, 2017) dengan judul hubungan media pembelajaran dan motivasi belajar terhadap prestasi belajar bidang studi Sejarah SMA Negeri 3 Lumajang. Hasil dari penelitiannya diketahui bahwa ada hubungan yang signifikan penggunaan media pembelajaran dan motivasi belajar secara bersama-sama terhadap prestasi belajar bidang studi sejarah siswa SMAN 3 Lumajang, yang ditunjukkan dengan probabilitas $F_{\text {hitung }}$ sebesar 0,039 yang lebih kecil dari $\alpha=0,05(p=0,039<\alpha=0,05)$.

Dalam menunjang sebuah pembelajaran dikelas pada dasarnya harus didukung oleh elemen-elemen penting yang mendukung didalamnya. Guru sebagai pengajar dikelas harus aktif dalam berkoordinasi dengan lingkungan belajar siswa. Sekolah sebagai layanan lembaga pendidikan bagi anak-anak yang ingin meraih citacitanya selalu berusaha untuk terus meningkatkan kualitas pembelajaran yang meliputi guru dan lingkungan belajar siswa (Susilo \& Irwansyah, 2019). Meskipun dalam pelaksanaan pembelajaran terdapat beberapa perbedaan antara misi, bentuk lembaga pendidikan atau sejenisnya, dalam kaitannya terhadap sumber belajar memiliki tujuan utama yaitu meningkatkan efektivitas dan efesiensi pembelajaran yang dikembangkan oleh guru secara keseluruhan. Maka tidak mengherankan bila dalam pelaksanaan pengajaran, guru banyak mengembangkan model dan media pembelajaran yang dikombinasikan dengan strategi pembelajaran yang inovatif. Semua hal yang dilakukan guru dalam mengajaran dasarnya tergantung kebutuhan dan ruang lingkung yang dikembangkan sebagai pusat belajar yang baik. Sumber belajar yang dikemas dalam beberapa media pembelajaran ini digunakan sebagai alat yang memudahkan guru dalam mentransfer ilmunya kepada siswa (Andarwati, 2019).

Seiring berkembangnya zaman memang tidak mengherankan jika peran media dalam pembelajaran sangat dominan untuk dilakukan guru selama pengajaran. Selain mengikuti tren era digital yang semakin canggih, juga untuk meningkatkan pemahaman materi yang dijelaskan oleh guru selama di kelas. Beberapa upaya agar siswa mudah memahami dilakukan oleh guru. Hal ini juga dikaitkan dengan kemajuan kurikulum yang berlaku. Dalam kurikulum 2013 sendiri, Sekolah dalam meningkatkan mutu pendidikan dituntut agar siswa sebagai obyek dalam meningkatkan kemampuannya. Peran guru disini adalah sebagai fasilitator yang member banyak 
arahan dan penjelasan yang siswa belum pahami. Siswa akan menjadi lebih aktif dan lebih kritis terhadap materimateri yang diajarkan (Andiyanto, 2017).

Dalam pembelajaran Sejarah yang banyak membahas materi seputar masa lampau sudah seharusnya guru Sejarah lebih sigap dalam meningkatkan kemampuan siswa. Menumbuhkan semangat siswa dalam belajar Sejarah sangat penting. Pembelajaran tidak selamanya dengan ceramah saja dan cara-cara konvensional. Guru Sejarah harus mampu menguasai lapangan bagaimana siswa mampu dikondisikan (Abror, Nur Fajar, 2019) Kombinasi penggunaan media pembelajaran dengan strategi yang bagus akan mampu memberikan dampak yang positif bagi dunia pendidikan. Siswa yang semakin ceria dalam menyambut pelajaran Sejarah tentunya akan berdampak pada hasil belajar siswa. Suatu sistem belajar yang dikembangkan oleh guru harus relevan dengan keadaan siswa yang ada saat ini. Hal ini dapat diwujudkan dengan langkah yang baik dengan pertimbangan yang matang. Guru Sejarah dapat memanfaatkan era teknologi yang dikombinasikan dengan kebutuhan siswa. Semangat guru Sejarah akan menjadi kekuatan guru Sejarah dalam mengajar dengan penuh keyakinan bahwa masa depan anak bangsa harus berhasil melalui pendidikan Sejarah di Sekolah (Tandirerung, Nasaruddin, 2017).

Jika dalam pembelajaran guru Sejarah menggunakan media video dalam meningkatkan pembelajarannya, tentunya hal tersebut telah melalui berbagai pertimbangan yang mendalam. Penggunaan video pembelajaran Sejarah sendiri dapat dilakukan secara tatap muka maupun online. Dalam video pembelajaran tersebut telah memuat isi materi yang dikombinasikan dengan elemen unsur suara dan tulisan. Melalui media video Sejarah ini, secara langsung bertujuan untuk meningkatkan motivasi belajar siswa dengan siswa sebagai pembelajar agar fokus terhadap materi yang menarik (Nugroho, 2019). Melalui media pembelajaran Sejarah berbasis video yang dikembangkan secara menarik ini diharapkan memberikan pengalaman bagi siswa. Adanya pengalaman belajar yang baik ini akan menumbuhkan semangat belajar dan hasil belajar yang sesuai keinginan Sekolah. Lebih jelasnya, media akan memudahkan guru dalam memberikan materi pelajaran. Media pembelajaran selain memberikan pengalaman belajar juga sebagai langkah untuk mengurangi rasa kebosanan siswa dalam mengikuti pelajaran di Sekolah.

Dari pernyataan diatas maka dapat simpulkan bahwa untuk menumbuhkan suatu semangat dalam belajar, guru Sejarah harus mampu berdampingan dengan kemajuan zaman. Di era globalisasi ini, guru harus mampu untuk berkreasi dengan perkembangan zaman yang ada. Pembelajaran Sejarah saat ini tidak hanya mengandalkan metode ceramah saja. Pembelajaran Sejarah yang dikembangkan guru sangat luas sekali. Maka guru harus lebih jeli dalam memilih media sebagai pendamping dalam pembelajaran. Media video Sejarah, animasi, visual dan beberapa media lainnya yang dikombinasikan dengan strategi pembelajaran akan berdampak pada peningkatan proses semangat dan hasil belajar Sejarah siswa.

\section{KESIMPULAN}

Dari hasil statistik diketahui bahwa $\mathrm{H}_{1}$ dalam meningkatkan semangat belajar Sejarah dengan hasil belajar siswa di Kelas X IPS SMA Negeri 5 Lubuklinggau diterima dimana hasil nilai $t_{\text {hitung }}$ 9,376 > 1,986. Sedangkan Ho yang tidak ada hubungan antara semangat belajar Sejarah dan hasil belajar siswa di kelas X IPS SMA Negeri 5 Lubuklinggau ditolak. Maka selanjutnya dapat dikatakan bahwa statistik yang didapatkan menunjukkan ada pengaruh yang signifikan antara semangat belajar Sejarah dengan hasil belajar siswa di kelas X IPS SMA Negeri 5 Lubuklinggau. Dari uji statistik ini jelas dalam pembelajaran memang tidak mudah dalam menumbuhkan semangat belajar bagi siswa. Maka guru Sejarah sebagai pengajar yang memahami keadaan siswa harus mampu meningkatkan pemahaman materi yang terjadi. Guru Sejarah dapat menggunakan berbagai macam media pembelajaran yang sesuai dengan kebutuhan siswa dikelas. Tentunya media yang dikemas tersebut harus disesuaikan dengan keadaan yang ada. Mengkombinasikan antara media dengan strategi pembelajaran agar menjadi menarik sangat perlu. Semangat dan perjuangan guru Sejarah dalam mengajar sangat penting dan member pengaruh yang besar bagi keberhasilan pendidikan.

\section{Ucapan Terima Kasih}

Kegiatan penelitian ini merupakan bagian dari kewajiban Dosen untuk melaksanakan Tri Darma Perguruan Tinggi di Kampus STKIP PGRI Lubuklinggau. dalam kegiatan penelitian ini, tim peneliti ingin mengucapkan banyak terima kasih kepada beberapa orang yang telah membantu kesuksesan dari penelitian sampai pada penulisan artikel ilmiah ini. ucapan terima kasih diucapkan kepada, yaitu: 
1. Bapak Dr. Rudi Erwandi, M.Pd selaku ketua STKIP PGRI Lubuklinggau yang telah memeberikan motivasi dan dorongan kepada kami selaku dosen untuk meningkatkan produktifitas dan kualitas penelitian.

2. Bapak Viktor Pandra, M.Pd selaku kepala LP4MK beserta staf nya yang telah banyak memberikan dukungan, fasilitas, administrasi guna kelancaran penelitian.

3. Bapak Jamaludin, M.Pd., Selaku Kepala Sekolah SMA Negeri 5 Lubuklinggau yang telah memberikan izin dalam penelitian di Sekolah tersebut.

4. Ibu Sisca Arie Hanika, M.Pd., sebagai penulis pendamping yang telah membantu dalam kegiatan penelitian dan penulisan artikel ilmiah.

5. Teman-teman Dosen dari Program Studi Pendidikan Sejarah STKIP PGRI Lubuklinggau yang telah memberikan dukungan dan semangat dalam penyelesaian penelitian ini.

6. Pihak-pihak lainnya yang tidak bisa kami sebutkan namanya satu persatu yang telah membantu dalam penyelesaian kegiatan penelitian ini.

\section{Daftar Pustaka}

Abror, Nur Fajar, dkk. (2019). Evaluasi Program Pembelajaran Sejarah Indonesia di SMKN 57 Jakarta. Jurnal PENDIDIKAN SEJARAH, 8(2), 170-194. https://doi.org/https://doi.org/10.21009/JPS.082.05

Aman. (2011). Model Evaluasi Pembelajaran Sejarah. Ombak.

Andarwati, M. (2019). Pembelajaran Sejarah Kontekstual, Kreatif, Menyenangkan di Kelas Dengan "Power Director" Bagi Generasi Z. Jurnal Pendidikan Sejarah Indonesia, 2(1), 64-81.

Andiyanto, T. (2017). Peran Guru Dalam Implementasi Kurikulum 2013: STUDI PADA TK Mentari Kec. Abung Selatan kab. Lampung Utara. Elementary: Jurnal Ilmiah Pendidikan Dasar, 3(1), 73-78.

Arikunto, S. (2014). Prosedur Penelitian Suatu Pendekatan Praktik. PT. Rineka Cipta.

Hidayat, A. (2018). Penggunaan Media Peta Pengaruhnya Terhadap Movitasi Belajar Sejarah Pada SMA Islam PB. Soedirman Cijantung Jakarta Timur. Jurnal Candrasangkala, 4(1), 14-20. https://doi.org/http://dx.doi.org/10.30870/candrasangkala.v4i1.3427

Joni. (2017). Hubungan Media Pembelajaran dan Motivasi Belajar Terhadap Prestasi Belajar Bidang Studi Sejarah Siswa SMA Negeri 3 Lumajang. Urnal Penelitian Dan Pendidikan IPS, 9(2), 1198-1209.

Nugroho, F. (2019). Penggunaan Sumber Belajar Dalam Pembelajaran Sejarah Kontroversial. NOSARARA: JURNAL PENDIDIKAN DAN ILMU SOSIAL, 7(2), 177-191.

Sanjaya, W. (2016). Strategi Pembelajaran Berorientasi Standar Proses Pendidikan. PRENADAMEDIA GROUP.

Sugiyono. (2015). Metode Penelitian Kuantitatif, Kualitatif, dan R $\mathcal{E}$ D. Alfabeta.

Susilo, A., \& Irwansyah, Y. (2019). Pendidikan Dan Kearifan Lokal Era Perspektif Global. SINDANG: Jurnal Pendidikan Sejarah Dan Kajian Sejarah, 1(1), 1-11. https://doi.org/10.31540/sdg.v1i1.193

Susilo, A., \& Sarkowi, S. (2018). Peran Guru Sejarah Abad 21 dalam Menghadapi Tantangan Arus Globalisasi. Historia: Jurnal Pendidik Dan Peneliti Sejarah, 2(1), 43. https://doi.org/10.17509/historia.v2i1.11206

Suyuti dan Ervina. (2020). Pengaruh Motivasi terhadap Hasil Belajar Sejarah Di SMAN 1 Palu. Jurnal Kreatif Online, 8(1), 145-152.

Tandirerung, Nasaruddin, dkk. (2017). Meningkatkan Hasil Belajar Sejarah Melalui Pendekatan Pembelajaran Konstruktivistik Pada Siswa Kelas XI IPS SMA Muhammadiyah 1 Palu. E Jurnal Katalogis, 5(7), 158-168.

Wa Fiana, dkk. (2018). Hubungan Minat Belajar dan Motivasi Belajar Siswa dengan Hasil Belajar IPS Siswa SD Negeri di Kecamatan Kendari. Jurnal Wahana Kajian Pendidikan IPS, 2(1), 242-248. https://doi.org/http://dx.doi.org/10.33772/jwkp-ips.v2i1.7488

Widayanti, F. D. (2013). Pentingnya Mengetahui Gaya Belajar Siswa Dalam Kegiatan Pembelajaran di Kelas. ERUDIO (Jurnal Of Educational Innovation), 2(1), 7-21. https://doi.org/https://doi.org/ 